\title{
Structure-Invading Pest Ants in Healthcare Facilities in Singapore
}

\author{
by \\ Lai-Sum Man ${ }^{1} \&$ Chow-Yang Lee ${ }^{2}$
}

ABSTRACT

A survey of structure-invading pest ants was conducted at 17 healthcare facilities (HFs) in Singapore using the index card method. A total of 18 species (Anoplolepis gracilipes (Fr. Smith), Meranoplus sp., Monomorium destructor (Jerdon), Monomorium floricola (Jerdon), Monomorium pharaonis (L.), Monomorium sp., Odontomachus sp., Oecophylla smaragdina (F.), Pachycondyla sp., Paratrechina bourbonica (Forel), Paratrechina longicornis (Latreille), Paratrechina pubens (Forel), Pheidole megacephala (F.), Pheidole parva (Mayr),Pheidolesp., Tapinomaindicum (Forel), Tapinomamelanocephalum (F.) andTetramorium bicarinatum (Nylander)) were trapped. Of these, the most common species were P. parva (25.9\%), P. megacephala (25.2\%), P. longicornis (14.1\%), M. pharaonis (9.6\%), and T. indicum (8.1\%). Most of these ant species were found in and around the premises.

\section{INTRODUCTION}

Singapore has a world-class healthcare system that was ranked sixth best in the world and the best in Asia by the World Health Organization in 2000. As Asia's leading medical hub, healthcare facilities (HFs) in Singapore emphasize excellence, safety, and trustworthiness (Lim 2004). This means that the public's expectations of quality service are high, and this includes low tolerance of pests within the premises. Nevertheless, the majority of HFs through out the world are prone to pest infestation (Burgess 1984). In Singapore, HFs are vulnerable to pest intrusion and infestation through numerous entrances, exits, and food establishments within the premises, as well as through win-

Urban Entomology Laboratory, Vector Control Research Unit, School of Biological Sciences, Universiti Sains Malaysia, 11800 Penang, Malaysia

${ }^{1}$ Present address: ISS Pest Management Pte Ltd, 51 Benoi Road Blk 8 \#01-02 Liang Huat Industrial Complex Singapore 629908.

${ }^{2}$ Corresponding author. Email: chowyang@usm.my 
dows, ceilings, wall cracks, and gaps around plumbing and pipes. They also can hitchhike in commercial deliveries and patient's clothing. In general, HFs provides an ideal environment in which pests can thrive (Murphy \& Oldbury 1996). Compared to other types of premises, HFs are sensitive environments because they house patients with compromised health. Pests can carry diseases, and in the process of eliminating pests, patients may be exposed to unforeseen pesticide risks that may not be easily diagnosed (Owens 2003).

Pest ants carry pathogens that may cause diseases that pose a threat to public health (Lee 2002). For example, pharaoh ants collected from nine hospitals were shown to carry numerous pathogenic organisms (Beatson 1972). Pharaoh ants also can contaminate food and sterile instruments (Beatson 1972, Wilkinson 1988). However, according to WHO (2008), no cases of patients being affected by pharaoh ant-mediated mechanical contamination have been reported. Fire ants pose a different risk; their stings are painful and cause a burning sensation (deShazo et al. 1990, WHO 2008). In addition, deaths due to an anaphylactic reaction to fire ant stings have been reported (deShazo et al. 1990, Rhoades et al. 1989).

Until now, information about pest ant infestation in HFs in Singapore has not been available. Surveys carried out in HFs in this study showed that pest ants are the major pest group affecting these facilities. The goal of this study was to determine the species composition of structure-invading pest ants in HFs in Singapore. The resulting data can be used to assist in the management efforts against pest ants in these facilities.

\section{MATERIALS AND METHODS}

Seventeen HFs in Singapore were surveyed. For ethical reasons, the identity of these facilities cannot be revealed. Of the $17 \mathrm{HFs}, 3,3,1,6$, and 4 were located in the north, northeast, east, central, and west parts of Singapore, respectively (Fig. 1). They were located in concentrated urban areas surrounded by plants, plots of greenery, open car parks, roads, sidewalks, and tree-lined streets.

Ants were collected using the index card method (Lee 2000, Lee \& Lee 2002, Lee et al. 2003). Blank index cards $(7.5 \times 12 \mathrm{~cm})$ baited with peanut butter $(24.3 \%$ protein and $47.2 \%$ fat) and honey ( $83 \%$ carbohydrate) were used to attract the ants. Baited index cards were placed at locations within the 
HFs where staff members had seen ant trails or activities, and each location was listed on a checklist. These locations included cafeterias, staff pantries, patient wards, offices, the building perimeter, and loading/unloading bays. All baited and placed index cards were checked for the presence of ants after 40-50 min. The ants on the index card were photographed using a digital camera (Nikon D90, Nikon Corp, Bangkok, Thailand). The ants then were collected, placed in plastic vials, and brought back to the laboratory for identification. Identifications were performed using astereoscopic zoom microscope (SMZ800, Nikon Corp., Yokohama, Japan) and using identification keys in AntWeb (2006), Hedges (2010), and Na and Lee (2001).

\section{RESULTS AND DISCUSSION}

Eighteen pest ant species were collected and identified (Table 1), and most were found both indoors and along the building perimeter of the HFs. Pheidoleparva Mayr and Pheidolemegacephala (F.) were the two most common ant species encountered; together they accounted for more than $50 \%$ of the total collection (25.9\% and 25.2\%, respectively). Earlier studies conducted in Malaysia also reported that $P$. megacephala was the most commonly found ant species (Lee et al. 2002, Na \& Lee 2001). In a survey conducted in urban

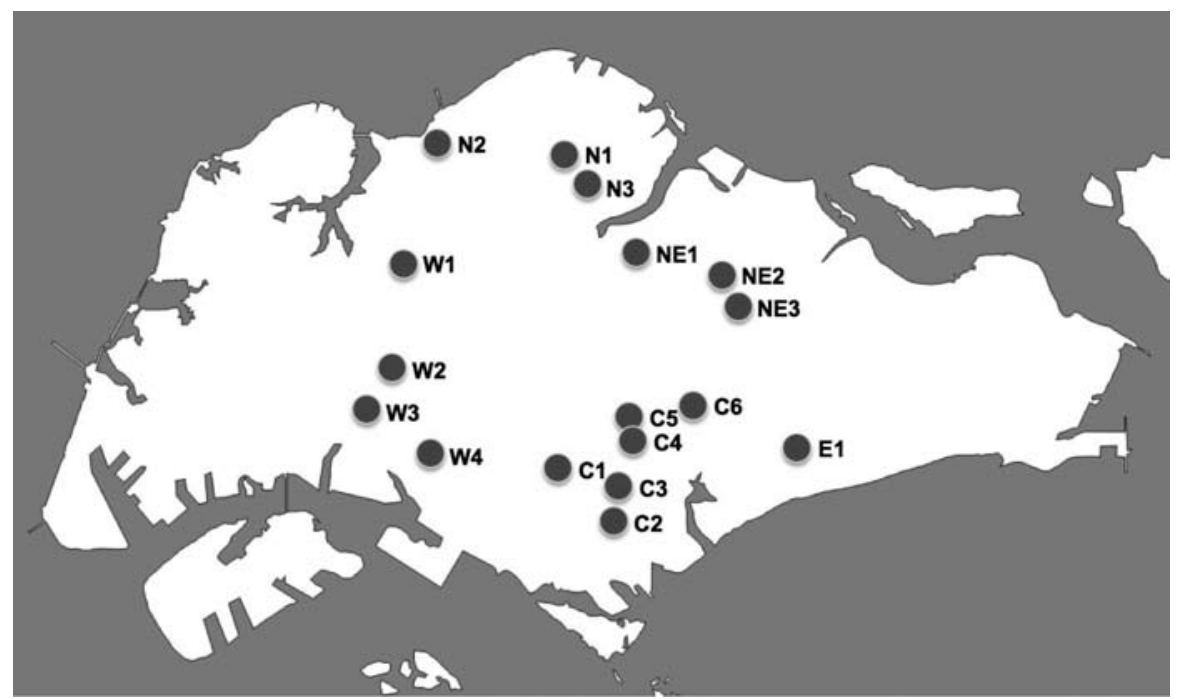

Fig. 1: A map of Singapore showing the locations of the healthcare facilities at which the pest ant surveys were conducted. 


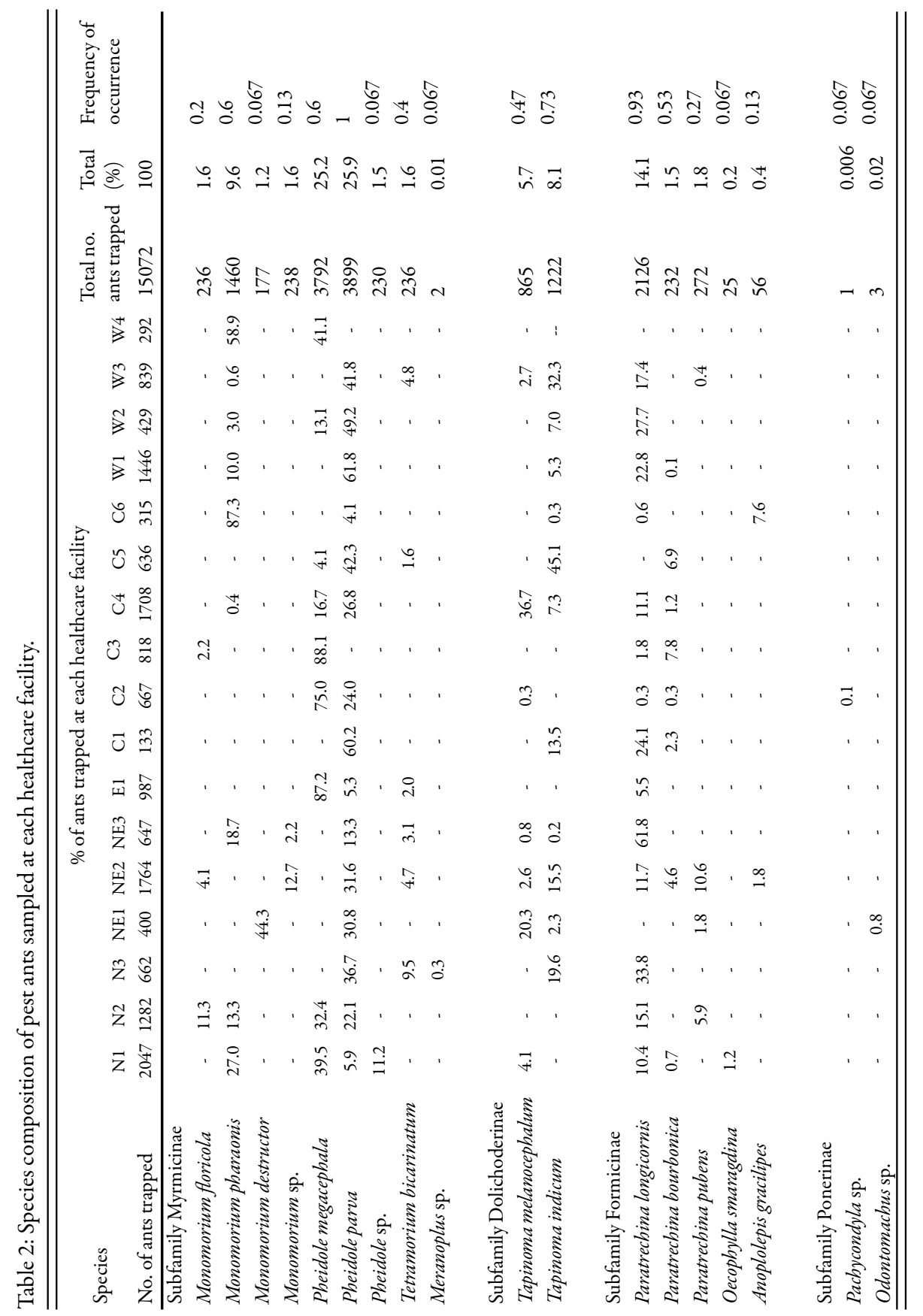


areas of Singapore in 2004 (Lee \& Tan 2004), there was no documentation of collection of $P$. parva. It is possible that $P$. parva was present but identified as Pheidole sp. More studies in other urban areas in Singapore are needed to determine whether the presence and dominance of $P$. parva is unique to areas around HFs in Singapore.

Crazy ants, Paratrechinalongicornis (Latreille) were the next most frequently encountered ant species (14.1\%), followed by pharaoh ants, Monomorium pharaonis (L.) at 9.6\% and ghost ants, Tapinoma indicum (Forel) at $8.1 \%$. In the past, it was reported the infestations of pharaoh ants only occurred indoors, but subsequent studies showed that they can occur in outdoor areas as well (Klotz et al. 1995, Knight \& Rust 1990). In our study, pharaoh ants were found both indoors and along outdoor perimeter areas. This may be due to Singapore's tropical climate, which allows pharaoh ants to establish nests or forage in outdoor areas due to the warm temperature (Kohn and Vlček 1986).

Five or more ant species were found within the vicinity of the majority of the HFs (> 75\%) surveyed (Table 2 ). The ant diversity within individual HFs might have been influenced by the surrounding landscape areas. Ant populations often are affected by vegetation structure, with a decrease in vegetation diversity causing a reduction in ant diversity because vegetation plays a major role in regulating the microclimatic conditions that affect ant activity (Perfecto \& Snelling 1995, Perfecto \& Vandermeer 1996, Retana \& Cerdá 2000, Vasconcelos et al. 2008).

Of the 18 ant species found in this study, P.parva had the highest frequency of occurrence (FO): It was found at 15 of the 17 HFs surveyed (Table 2). However, $P$. parva was not always the most abundant species found at those HFs (<50\%). P. longicornis had the highest FO (0.93) after P.parva. P. longicornis can thrive well in HFs because the facilities generally are surrounded by greenery, such as trees, planters, and lawns; landscape mulch, the undersides of potted plants and logs, and tree holes provide ideal nesting sites for crazy ants (Hedges 2010). P. longicornis also can forage long distances from their nest (Jaffe 1993), and their quick random movements while foraging for food (Lee 2002) help them locate food sources quickly.

P. megacephala had the fourth highest FO (0.6) after T. indicum $(\mathrm{FO}=$ 0.73 ) although it was the most abundant ant species in five of the nine HFs 
Table 1: The pest ant species sampled and collection locations at the healthcare facilities.

\begin{tabular}{|c|c|c|c|c|c|}
\hline \multirow{2}{*}{ Species } & \multirow{2}{*}{ Common name } & \multicolumn{2}{|c|}{ Location collected } & \multirow{2}{*}{$\begin{array}{l}\text { Total number } \\
\text { of ants trapped }\end{array}$} & \multirow{2}{*}{ Total (\%) } \\
\hline & & Indoors & $\begin{array}{l}\text { Outdoor } \\
\text { perimeter }\end{array}$ & & \\
\hline \multicolumn{6}{|l|}{ Subfamily Myrmicinae } \\
\hline Monomorium floricola & None & $\mathrm{x}$ & $\mathrm{x}$ & 236 & 1.6 \\
\hline Monomorium pharaonis & Pharaoh ant & $\mathrm{x}$ & $\mathrm{x}$ & 1460 & 9.6 \\
\hline Monomorium destructor & Singapore ant & $\mathrm{x}$ & - & 177 & 1.2 \\
\hline Monomorium sp. & None & - & $\mathrm{x}$ & 238 & 1.6 \\
\hline Pheidole megacephala & Big-headed ant & $\mathrm{x}$ & $\mathrm{x}$ & 3792 & 25.2 \\
\hline Pheidole parva & None & $\mathrm{x}$ & $\mathrm{x}$ & 3899 & 25.9 \\
\hline Pheidole sp. & None & - & $\mathrm{x}$ & 230 & 1.5 \\
\hline Tetramorium bicarinatum & Guinea ant & $\mathrm{x}$ & $\mathrm{x}$ & 236 & 1.6 \\
\hline Meranoplus sp. & None & - & $\mathrm{x}$ & 2 & 0.01 \\
\hline \multicolumn{6}{|l|}{ Subfamily Dolichoderinae } \\
\hline Tapinoma melanocephalum & Ghost ant & $\mathrm{x}$ & $\mathrm{x}$ & 865 & 5.7 \\
\hline Tapinoma indicum & Ghost ant & $\mathrm{x}$ & $\mathrm{x}$ & 1222 & 8.1 \\
\hline \multicolumn{6}{|l|}{ Subfamily Formicinae } \\
\hline Paratrechina longicornis & Crazy ant & $\mathrm{x}$ & $\mathrm{x}$ & 2126 & 14.1 \\
\hline Paratrechina bourbonica & Robust crazy ant & - & $\mathrm{x}$ & 232 & 1.5 \\
\hline Paratrechina pubens & Hairy crazy ant & $\mathrm{x}$ & $\mathrm{x}$ & 272 & 1.8 \\
\hline Oecophylla smaragdina & Weaver ant & - & $\mathrm{x}$ & 25 & 0.2 \\
\hline Anoplolepis gracilipes & Long-legged ant & $\mathrm{x}$ & $\mathrm{x}$ & 56 & 0.4 \\
\hline \multicolumn{6}{|l|}{ Subfamily Ponerinae } \\
\hline Pachycondyla sp. & None & - & $\mathrm{x}$ & 1 & 0.006 \\
\hline Odontomachus sp. & None & - & $\mathrm{x}$ & 3 & 0.02 \\
\hline
\end{tabular}

in which it was found. The high abundance of this species in some locations may occur because few other ant species are present in locations where $P$. megacephala occurs. Invasion by $P$. megacephala reportedly reduced the native ant species and other invertebrate species (Tryon 1912, Vanderwoude et al. 2000), but its foraging activity declined when other tramp ant species (e.g., P. longicornis and M. pharaonis) were present (Loke \& Lee 2004).

Only a small percentage of Anoplolepis gracilipes (Fr. Smith) was found in two HFs $(\mathrm{FO}=0.13)$. This is a highly invasive ant species, and Chong and Lee (2010) reported that it showed aggressive behavior towards other tramp ant species such as M. pharaonis, Monomorium floricola (Jerdon), Monomorium 
destructor (Jerdon), P. parva, T. indicum, Tapinoma melanocephalum (F.), P. longicornis, and Oecophylla smaragdina (F.). Our finding differs from results from Malaysia, where an increase in $A$. gracilipes infestations has occurred in the past few years (Chong \& Lee 2010). This difference could be due to the differences in survey locations.

Many of the ant species trapped in the survey were tramp ants. Tramp ants are considered the most difficult group of ants to control, as they thrive successfully in environments where human activities provide them with shelter, moisture and food, which ensure their survival (Hedges 2001, Silverman 2005).

This study had several limitations. Not all of the indoor areas were surveyed, as some areas were no-entry zones for pest management professionals. Other areas could not be sampled because hospital authorities wanted to avoid unnecessary questioning from the patients or the public and thus would not grant permission.

In Singapore, food manufacturing plants are among the few sectors that demand and implement the best possible pest management programs. These programs heavily emphasize exclusion methods to prevent pest intrusion and limit the use of chemical treatments to ensure food safety. HFs are another sensitive environment, as they house patients who have serious health conditions. More studies are needed in the HFs of Singapore to develop a sustainable pest management program that focuses on integration of various methods to control pests, with use of insecticides only as the last option.

\section{ACKNOWLEDGMENTS}

The authors thank A.L.-C. Seow, K.-H. Teo, L.-Y. Lim and A. Nasir of ISS Pest Management Pte Ltd., Singapore for support and technical assistance; Dr Y.-F. How and E.H.-P. Lim for valuable comments on the manuscript. The work reported herein is a section of the graduate research project of the senior author (L.-S.M).

\section{REFERENCES}

AntWeb, 2006. http://www.antweb.org/ (accessed 11/05/2011).

Beatson, S.H. 1972. Pharaoh's ants as pathogen vectors in hospitals. Lancet 1: 425-427.

Burgess, N.R.H. 1984. Hospital design and cockroach control. Trans. Roy. Soc. Trop. Med.

Hyg. 78: 293-294. 
Chong, K.F. \& C.Y. Lee 2010. Inter- and intraspecific aggression in the invasive longlegged ant (Hymenoptera: Formicidae). J. Econ. Entomol. 103: 1776-1783.

deShazo, R.D., B.T. Butcher, \& W.A. Banks 1990. Reactions to the stings of the imported fire ant. N.E. J. Med. 323: 462-466.

Hedges, S.A. 2001. The best of Stoy Hedges. GIE Media Inc Publishers, 368 pp.

Hedges, S.A. 2010. Field guide for the management of structure-infesting ants. $3^{\text {rd }}$ edition. GIE Inc Publishers, Richfield, Ohio. 325 pp.

Jaffe, K. 1993. Surfing ants. Flor. Entomol. 76: 182-183.

Klotz, J.H., J.R. Mangold, K.M. Vail, L.R. Davis, Jr., \& R.S. Patterson 1995. A survey of the urban pest ants (Hymenoptera: Formicidae) of peninsular Florida. Flor. Entomol. 78: 109-118.

Knight, R.L. \& M.K. Rust 1990. The urban ants of California with distribution notes of imported species. Southwest Entomol. 15: 167-178.

Kohn, M. \& M. Vlček 1986. Outdoor persistence throughout the year of Monomorium pharaonis (Hymenoptera: Formicidae). Entomol. Gener. 11:213-215.

Lee, C.Y. 2000. Performance of hydramethylnon- and fipronil-based containerized baits against household ants in residential premises. Trop. Biomed. 17: 45-48.

Lee, C.Y. 2002. Tropical household ants: Pest status, species diversity, foraging behavior and baiting studies. pp. 3-18. In: S.C. Jones, J. Zhai \& W. H. Robinson [eds.], Proceedings of the $4^{\text {th }}$ International Conference On Urban Pests. Pocahontas Press, Blacksburg, Virginia.

Lee, C.Y. \& L.C. Lee 2002. Field and laboratory evaluation of a boron-based containerized dual-bait formulation against the Pharaoh ant, Monomoriumpharaonis (Hymenoptera: Formicidae). Sociobiology 40: 655-665.

Lee, C.Y., C.Y. Lim, \& I. Darah 2002. Survey on structure-infesting ants (Hymenoptera: Formicidae) in food preparative outlets. Trop. Biomed. 19: 21-26.

Lee, C.Y., J. Zairi, H.H. Yap, \& N.L. Chong 2003. Urban pest control - A Malaysian perspective. Second edition. Universiti Sains Malaysia Press, Penang, Malaysia.

Lee, C.Y.\&E.K. Tan 2004. Guide to urban pest ants of Singapore. SPMA for Pest Management Professionals, Singapore. 40 pp.

Lim, M.K. 2004. Quest for quality care and patient safety: The case of Singapore. BMJ Quality Safety 13: 71-75

Loke, P.Y \& C.Y. Lee 2004. Foraging behaviour of field populations of big-headed ant, Pheidole megacephala (Hymenoptera: Formicidae). Sociobiology 43: 211-219.

Murphy, R.G. \& D.J. Oldbury 1996. The role of environment health departments in ensuring pest free hospitals. pp. 579-586. In: K.B. Wildey [eds], Proceedings of the $2^{\text {nd }}$ International Conference on Urban Pests.

Na, J.P.S. \& C.Y. Lee 2001. Identification key to common urban pest ants in Malaysia. Trop. Biomed. 18: 1-17.

Owens, K. 2003. Healthy Hospitals: Controlling Pests Without Harmful Pesticides. Washington DC: Health Care Without Harm \& Beyond Pesticides. 57 pp.

Perfecto I. \& R. Snelling 1995. Biodiversity and the transformation of a tropical agroecosystem: 
Ants in coffee plantations. Ecol. Appl. 5: 1084-1097.

Perfecto, I. \& J. Vandermeer 1996. Microclimatic changes and the indirect loss of ant diversity in a tropical agroecosystem. Oecologia 108: 577-582.

Retana J. \& X. Cerdá 2000. Patterns of diversity and composition of Mediterranean ground ant communities: Tracking spatial and temporal variability in the thermal environment. Oecologia 123: 436-444.

Rhoades, R.B., C.T. Stafford, \& F.K. James, Jr. 1989. Survey of fatal anaphylactic reactions to imported fire ants stings. J. Allergy Clin. Immunol. 84: 159-162.

Silverman, J. 2005. Why do certain ants thrive in the urban environment? pp. 29-31. In:

C.Y. Lee \& W.H. Robinson [eds], Proceedings of the Fifth International Conference on Urban Pests, Perniagaan Ph'ng@ P\&Y Design Network, Malaysia.

Tyron, H. 1912. The naturalization of an exotic ant (Pheidole megacephala Fab.). Qld Nat. 1: 224-229.

Vanderwoude, C., L.A. Lobry De Bruyn, \& A.P.N. House 2000. Response of an open-forest ant community to invasion by the introduced ant, Pheidole megacephala. Austral Ecol. 25: 253-259.

Vasconcelos, H.L, M.F. Leite, J.M.S. Vilhena, A.P. Lima, \& W.E. Magnusson 2008. Ant diversity in an Amazonian savanna: Relationship with vegetation structure, disturbance by fire, and dominants ants. Austral. Ecol. 33: 221-231.

WHO 2008. Public health significance of urban pests. WHO Regional Office for Europe. 569 pp.

Wilkinson, P.J. 1988. Food hygiene in hospitals. J. Hosp. Infect. 11: 77-81. 
